\title{
ASSESSMENT OF THE IMPACT OF EXTERNAL ENVIRONMENT ON FINTECH DEVELOPMENT
}

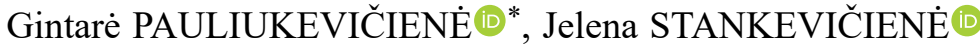 \\ Department of Financial Engineering, Faculty of Business Management, \\ Vilnius Gediminas Technical University, Sauletekio al. 11, LT-10223 Vilnius, Lithuania
}

Received 28 February 2021; accepted 01 April 2021

\begin{abstract}
Purpose - to propose an assessment tool of the environment of FinTech sector.
Research methodology - systematic analysis of scientific literature has been carried out to form a methodology for FinTech sector environment assessment, which consists of quantitative methods used for the empirical research of the study as follows: PEST analysis, expert evaluation, determination of indicators' values, normalization of data, multi-criteria assessment (the Simple Additive Weighting (SAW) method).

Findings - the practical application of the developed assessment tool is verified by completing an empirical study on the example of the leading FinTech countries as well as the Baltic States. Recommendations for further Lithuanian FinTech sector development are provided.

Research limitations - research is based on an assessment of the significance of external environmental indicators of FinTech sector development on a country level. Due to the large number of indicators and countries, only a fraction of factors and countries were selected for research. Therefore, the object of the research requires a more detailed study in the future.

Practical implications - the development of FinTech sector has been growing dramatically in the recent years on a global scale, with some countries leading the way due to a more favourable environment. The results show that the proposed assessment tool for the development of the FinTech sector can be used by policymakers in different countries to identify the external environmental factors to improve in order to create better conditions for the development of the FinTech sector.

Originality/Value - a new methodology and tool for FinTech environment assessment is developed by the authors as a contribution to the formation of better environment for FinTech sector development. The developed tool provides an opportunity to study the strong and weak sides of the environment development of the FinTech sector, to compare the good practices of other countries and to get ideas for changes in order to create a more favourable environment for the FinTech development on a country level.
\end{abstract}

Keywords: FinTech development, environment assessment, PEST Analysis, external environmental indicators, multi-criteria methods, SAW method.

JEL Classification: G18, G28, O11, O32, O44, Q55.

Conference topic: Contemporary Financial Management.

\section{Introduction}

The development of FinTech sector has been growing dramatically in the recent years on a global scale, with some countries leading the way due to a more favorable environment. The total global investment activity (VC, $\mathrm{PE}$ and M\&A) in FinTech in 2017 was $\$ 60.2$ billion, while in 2018 and 2019 it amounted to $\$ 150.4$ billion annually, which is more than double (KPMG International, 2020). 2020, as global Covid-19 pandemic year, brought some challenges to FinTech sector, as any other sector. However, it brought some new opportunities as well, and despite a noticeable slowdown in the growth of FinTech, it still continued, which once again proves FinTech sector development potential in this digital age.

*E-mail: gintare.pauliukeviciene@gmail.com

(C) 2021 Authors. Published by Vilnius Gediminas Technical University. This is an open-access article distributed under the terms of the Creative Commons Attribution (http://creativecommons.org/licenses/by/4.0/) License, which permits unrestricted use, distribution, and reproduction in any medium, provided the original author and source are credited. 
The importance of FinTech sector development and its' external environment is also demonstrated by the fact that it is gradually being examined by researchers and analysts - over the last five years, the environment influencing the development of FinTech sector has become a significant object of research. Factors influencing the sector growth are studied, countries and cities are compared in various aspects (Hieminga et al., 2016; fDi Intelligence, 2019; Findexable, 2019; Frost, 2020; Boitan \& Barbu, 2021). The European Commission also pays special attention to the development of FinTech as one of its priority areas with FinTech Action Plan 2018 and Digital Finance Strategy 2020, where the importance of proper legislation and digital resilience is emphasized. All these strategic documents, studies and their findings highlight the importance of external environmental factors for FinTech sector development. However, it can be argued that research to date lacks integrity and universality of results - it emphasizes the influence of different environments and factors, and the proposed indices are applicable to only some countries. There is a clear need for a universal assessment tool of the environment of FinTech sector, indicating the main drivers. Therefore, the object of this study is FinTech development. The purpose of this study is to propose an assessment tool of the environment of FinTech sector. The article consists of four sections: the first section explores recent scientific publications referred in scientific databases, most of the published not earlier than 2016, the second section explains the empirical methodological part and methodological process of research, third section introduces to the results and findings of the research as well as future recommendations, and fourth section comes up with the conclusions, research limitations and further research perspectives. Researchers use analysis of scientific literature and multicriteria decision support method (SAW).

\section{Literature review on the assessment of external environment impact on FinTech development}

The FinTech sector, like any other business sector, is expected to evolve and operate under a particular set of external macro-environmental factors, which are characterized by an extremely high degree of dynamism, complexity, and uncertainty (Shtal et al., 2018). These factors are treated as given and are generally uncontrollable for any business sector, since no business can influence the external environment and can only adapt to it. However, the macroeconomic environment may be affected by country's government in the long run, as well as business has the opportunity and freedom to choose in which country to carry out / relocate / expand its activities. For both purposes, in order to make the right choices, it is important to assess the external environment of the FinTech sector on a country level.

The articles and other sources for this research were chosen out of those referred in the scientific databases, such as Google Scholar and others. The articles and other sources were chosen using the keywords "FinTech development", "environment assessment", "external environmental indicators", "FinTech Index", "FinTech ranking". Only 11 scientific articles were found where part of the keywords are mentioned in the period between 2015 and 2021. A gap in research focused on external environment indicators influencing FinTech sector development is undoubtedly noticed. The literature review on the assessment of external environment impact on FinTech development is presented below in chronological order.

In 2007, Z/Yen and the City of London released the first edition of the Global Financial Centres Index, providing evaluations of competitiveness and rankings for the major financial centres (cities) around the world. For the last 13 years researchers from Z/Yen Partners and China Development Institute have published two reports a year charting the progress of the world's leading financial centres. In the latest twenty-ninth edition, the cities are rated on a global level according to the business environment, human capital, infrastructure, financial sector development and reputation, with some special focus on FinTech (Morris et al., 2021).

In 2016, researchers from ING Bank Economics Department introduced a FinTech index for low and middle-income countries across the world with a purpose to assess a country's need for FinTech led financial inclusion, FinTech infrastructure as well as country-specific governance and demographic features (Hieminga et al., 2016). This study was the first of its kind to provide a basis for further research on external environment importance to FinTech development, but was not further developed or continued by the authors.

A period of 2017-2018 represents a lack of research on the topic of this study, since no new FinTech Indexes or rankings were suggested by the researchers.

In 2019, a group of researches introduced a new approach and launched a Global FinTech Index with a purpose to identify and rank some countries and cities worldwide as FinTech ecosystems and companies according to the strength of their FinTech ecosystem. According to this approach, the most important indicators influencing the FinTech development are the quantity of FinTech's and ecosystem developers, the impact of individual companies in a location relative to one another, and business environment (Findexable, 2019). Although the suggested assessment tool is innovative, it partially covers only the political and economic environment of FinTech development.

In the same year, other researchers proposed a different ranking of global cities, focusing on FinTech infrastructure, foreign direct investment performance, costs effectiveness, economic potential, innovation and attractiveness as the main indicators influencing the FinTech development, which mostly covers technological and economic environments of FinTech sector (fDi Intelligence, 2019). 
In 2020, Startup Genome, the world-leading policy advisory and research organization for governments and public-private partnerships, committed to accelerating the success of startup ecosystems, introduced Global FinTech Ranking, evaluating FinTech ecosystems (cities) according to performance, funding, talent, focus and legacy (Gauthier et al., 2020).

In 2021, researchers from Bucharest University of Economic Studies has proposed a European Union (EU) Fintech index, relying on the same methodological steps and variables as proposed by ING's FinTech index, focusing exclusively on EU countries, with a purpose to evaluate countries' opportunities for FinTech growth (Boitan \& Barbu, 2021). Although the assessment tool was developed five years ago and newly adapted to different target group, it partially covers political, economic, social and technological environments of FinTech development.

Over the last five years, some other research was conducted on the topic of FinTech development (Arner et al., 2015; EY, 2015, 2017, 2019; Nicoletti et al., 2017; Mention, 2019) and the impact of its' external environment (Sahay et al., 2020; Goo \& Heo, 2020; Frost, 2020), which was taken into consideration in further research of this paper.

To sum up the chronological scientific literature review, a comparative analysis of the existing FinTech environment assessment tools and their components is created by the authors. The analysis, presented in Table 1, shows, that there is a clear research gap - there is no universal assessment tool for FinTech sector environment, adaptable to every country. Currently existing tools are limited either by the target group or by environment and indicators.

Different methods of strategic analysis for business environment assessment are considered by researchers. The most common frameworks in the scientific literature are SWOT analysis, PEST analysis, STEP analysis, GRID analysis, SNW analysis, EFAS form and others (Shtal et al., 2018). Some methodological redirections for an evolutionary approach of the external business environment are also in consideration (Vlados \& Chatzinikolaou, 2019). However, PEST analysis, which is an acronym for political, economic, social and technological factors, is the most common approach for considering the external business environment, describing a framework of macro-environmental factors used in the environmental scanning component of strategic management (Gupta, 2013). A great and simple example capturing the FinTech environment using PEST analysis is provided in Estonia's FinTech Report 2019 (Tirmaste et al., 2019). Therefore, the authors have chosen to propose an assessment tool of the environment of FinTech sector by carrying out a PEST analysis of FinTech sector environment, which would be suitable and adaptable to every country. The composition of an assessment tool for FinTech sector environment based on PEST analysis of FinTech sector external environmental indicators, created by the authors, is presented in Table 2. The suggested composition was prepared by the authors as follows: a list of possible indicators for each environment was drawn up based on the

Table 1. Comparative analysis of the existing FinTech environment assessment tools and their components (source: created by the authors, 2021)

\begin{tabular}{|c|c|c|c|c|c|c|c|c|c|c|c|c|c|c|}
\hline \multirow[b]{2}{*}{ Authors } & \multirow[b]{2}{*}{$\begin{array}{l}\text { Target group of } \\
\text { the FinTech Index }\end{array}$} & \multicolumn{13}{|c|}{ Indicators / Data points } \\
\hline & & 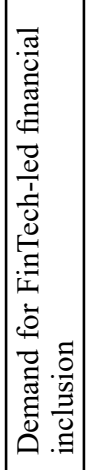 & 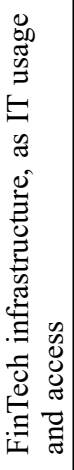 & 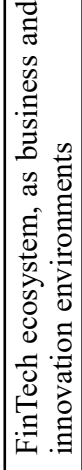 & 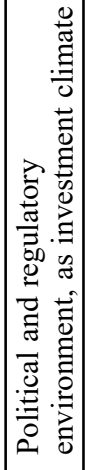 & 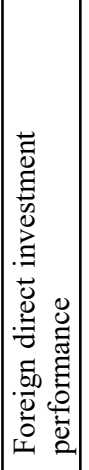 & 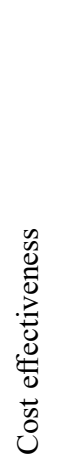 & 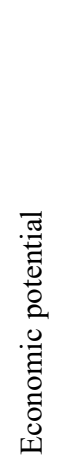 & 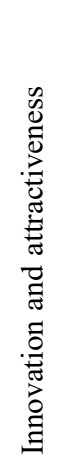 & 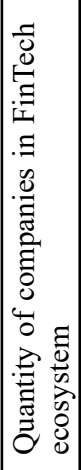 & 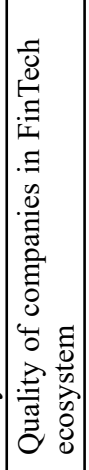 & 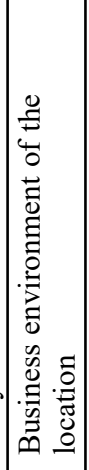 & 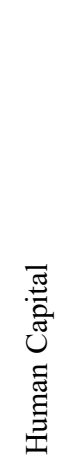 & 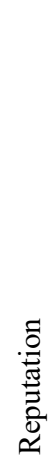 \\
\hline $\begin{array}{l}\text { Hieminga et al. } \\
\text { (2016) }\end{array}$ & $\begin{array}{l}\text { Developing and emerging } \\
\text { countries }\end{array}$ & + & + & + & + & & & & & & & & & \\
\hline $\begin{array}{l}\text { fDi Intelligence } \\
\text { (2019) }\end{array}$ & Global locations (cities) & & + & & & + & + & + & + & & & & & \\
\hline $\begin{array}{l}\text { Findexable } \\
\text { (2019) }\end{array}$ & $\begin{array}{l}\text { Global ecosystems (cities } \\
\text { and countries) and companies }\end{array}$ & & & & & & & & & + & + & + & & \\
\hline $\begin{array}{l}\text { Gauthier et al. } \\
\text { (2020) }\end{array}$ & Global ecosystems (cities) & & & + & & + & + & & & + & + & & + & \\
\hline $\begin{array}{l}\text { Boitan and } \\
\text { Barbu (2021) }\end{array}$ & European Union countries & + & + & + & + & & & & & & & & & \\
\hline $\begin{array}{l}\text { Morris et al. } \\
\text { (2021) }\end{array}$ & $\begin{array}{l}\text { Global financial centres } \\
\text { (cities) }\end{array}$ & & + & & & & & + & & & & + & + & + \\
\hline
\end{tabular}


literature review; correlating with each other indicators were removed; data collection was carried out - indicators for which no data for 2020 were available at the time of data collection were removed. As a result, an assessment tool was made up of 4 different environments with 8 different indicators in each environment, which makes a total of 32 indicators.

Table 2. Composition of an assessment tool for FinTech sector environment based on PEST analysis of FinTech sector external environmental indicators (source: created by the authors, 2021)

\begin{tabular}{|c|c|c|}
\hline Environment & Indicator & Explanation of the Indicator \\
\hline \multirow{8}{*}{$\stackrel{\substack{: \\
:}}{\circ}$} & Access to finance (P1) & $\begin{array}{l}\text { The strength of credit reporting systems and the effectiveness of collateral and } \\
\text { bankruptcy laws in facilitating lending (World Bank, 2019). }\end{array}$ \\
\hline & $\begin{array}{l}\text { Governance efficiency } \\
\text { (P2) }\end{array}$ & $\begin{array}{l}\text { Results of core state areas and investments, the provision of a framework for sustained } \\
\text { and sustainable wealth generation (SolAbility, 2020). }\end{array}$ \\
\hline & Government size (P3) & Government spending, tax burden, fiscal health (Miller et al., 2020). \\
\hline & $\begin{array}{l}\text { Openness to business } \\
\text { (P4) }\end{array}$ & $\begin{array}{l}\text { Levels of bureaucracy and corruption, manufacturing costs, favorability of tax } \\
\text { environment and transparency of government practices (U.S.News \& World Report LP, } \\
\text { 2020). }\end{array}$ \\
\hline & Open Markets (P5) & Trade freedom, investment freedom, financial freedom (Miller et al., 2020). \\
\hline & $\begin{array}{l}\text { Political globalization } \\
\text { (P6) }\end{array}$ & $\begin{array}{l}\text { Number of international embassies, missions, NGOs and other organisations, treaties } \\
\text { and investment partners (Dreher, 2006; Gygli et al., 2019; KOF Swiss Economic } \\
\text { Institute, 2020). }\end{array}$ \\
\hline & $\begin{array}{l}\text { Regulation } \\
\text { environment for } \\
\text { starting a business (P7) }\end{array}$ & $\begin{array}{l}\text { Number of procedures, time, cost and paid-in minimum capital requirement for a } \\
\text { SME to start up and formally operate in economy's largest business city (World Bank, } \\
\text { 2019). }\end{array}$ \\
\hline & Rule of law (P8) & Property rights, government integrity, judicial effectiveness (Miller et al., 2020). \\
\hline \multirow{8}{*}{ 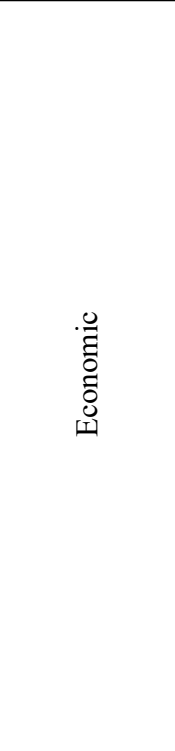 } & $\begin{array}{l}\text { Attractiveness and } \\
\text { competitiveness of the } \\
\text { country as a Fintech } \\
\text { Nation (E1) }\end{array}$ & Fintech activity and the development of local fintech ecosystem (Findexable, 2019). \\
\hline & $\begin{array}{l}\text { Attractiveness and } \\
\text { competitiveness of } \\
\text { the leading city as a } \\
\text { Fintech City (E2) }\end{array}$ & $\begin{array}{l}\text { Quantity and quality of companies in an ecosystem, business environment of the } \\
\text { location (Findexable, 2019). }\end{array}$ \\
\hline & $\begin{array}{l}\text { Economic } \\
\text { globalization (E3) }\end{array}$ & $\begin{array}{l}\text { Level of financial and trade globalization (Dreher, 2006; Gygli et al., 2019; KOF } \\
\text { Swiss Economic Institute, 2020). }\end{array}$ \\
\hline & Inflation rate $(\mathrm{E} 4)$ & Average consumer prices, annual percent change (International Monetary Fund, 2020). \\
\hline & GDP per capita (E5) & $\begin{array}{l}\text { Current prices, purchasing power parity; international dollars per capita (International } \\
\text { Monetary Fund, 2020). }\end{array}$ \\
\hline & Natural capital (E6) & $\begin{array}{l}\text { The given natural environment, including the availability of resources, and the level of } \\
\text { the depletion of those resources (SolAbility, 2020). }\end{array}$ \\
\hline & Real GDP growth (E7) & Annual percent change (International Monetary Fund, 2020). \\
\hline & $\begin{array}{l}\text { Resource efficiency } \\
\text { and intensity (E8) }\end{array}$ & $\begin{array}{l}\text { The efficiency of using available resources as a measurement of operational } \\
\text { competitiveness in a resource-constraint World (SolAbility, 2020). }\end{array}$ \\
\hline \multirow{8}{*}{$\begin{array}{l}\frac{\pi}{0} \\
0 \\
0\end{array}$} & Entrepreneurship (S1) & Level of entrepreneurship (U.S.News \& World Report LP, 2020). \\
\hline & $\begin{array}{l}\text { Intellectual capital and } \\
\text { innovation (S2) }\end{array}$ & $\begin{array}{l}\text { Capability to generate wealth and jobs through innovation and value-added industries } \\
\text { in the globalized markets (SolAbility, 2020). }\end{array}$ \\
\hline & Population (S3) & $\begin{array}{l}\text { Millions of people as a potentially sufficient customer base / market for the } \\
\text { development of the sector (International Monetary Fund, 2020). }\end{array}$ \\
\hline & $\begin{array}{l}\text { Progress of human } \\
\text { development (S4) }\end{array}$ & Life expectancy and health, human knowledge, standard of living (Conceicao, 2020). \\
\hline & Social capital (S5) & Security, freedom, equality and life satisfaction within a country (SolAbility, 2020). \\
\hline & $\begin{array}{l}\text { Social globalization } \\
\text { (S6) }\end{array}$ & $\begin{array}{l}\text { Level of interpersonal, informational and cultural globalization (Dreher, 2006; Gygli } \\
\text { et al., 2019; KOF Swiss Economic Institute, 2020). }\end{array}$ \\
\hline & Talent availability (S7) & $\begin{array}{l}\text { Amount of skilled workforce and its' sustainability based on emerging and aging } \\
\text { workforce trends (ManpowerGroup Talent Solutions, 2020). }\end{array}$ \\
\hline & Quality of life (S8) & $\begin{array}{l}\text { Quality of life in a country: affordability, labor market, economic stability, family } \\
\text { friendliness, income equality, political stability, security, development of public } \\
\text { education and health systems (U.S.News \& World Report LP, 2020). }\end{array}$ \\
\hline
\end{tabular}


End of Table 2

\begin{tabular}{|c|c|c|}
\hline Environment & Indicator & Explanation of the Indicator \\
\hline \multirow{8}{*}{$\begin{array}{l}\vec{J} \\
.00 \\
00 \\
0 \\
0 \\
0 \\
0 \\
0 \\
0\end{array}$} & Digitalization (T1) & Progression of digital economy (Chakravorti et al., 2020). \\
\hline & E-Participation (T2) & Citizenry access to information and public services (United Nations, 2020). \\
\hline & Internet speed (T3) & Fixed broadband and mobile speed, Mbps (Speedtest, 2020). \\
\hline & $\begin{array}{l}\text { National cyber security } \\
\text { (T4) }\end{array}$ & $\begin{array}{l}\text { Level of cyber security, preparedness to prevent and fight cyber-attacks and crimes } \\
\text { (National Cyber Security Index, 2020). }\end{array}$ \\
\hline & $\begin{array}{l}\text { Network readiness } \\
\text { (T5) }\end{array}$ & Application and impact of ICT in economy (Portulans Institute, 2020). \\
\hline & Online service (T6) & Scope and quality of online services (United Nations, 2020). \\
\hline & $\begin{array}{l}\text { Research and } \\
\text { development (T7) }\end{array}$ & $\begin{array}{l}\text { Researchers, gross expenditure on R\&D, global R\&D companies, QS university } \\
\text { ranking (Cornell University, INSEAD, \& WIPO, 2020). }\end{array}$ \\
\hline & $\begin{array}{l}\text { Telecommunication } \\
\text { infrastructure (T8) }\end{array}$ & $\begin{array}{l}\text { Users and subscribers of the internet, mobile, mobile-broadband, fixed broadband } \\
\text { (United Nations, 2020). }\end{array}$ \\
\hline
\end{tabular}

\section{Research methodology}

Methods of systematic and comparative analysis, logic and synthesis were applied in the paper, which allowed to emphasize the views of different scientists and reveal the problems of the environment assessment of FinTech sector. The research methodology of this paper consists of the following research methods:

1. Scientific literature analysis. The articles referred to in the scientific databases, such as Google Scholar and others, during the period of 2015-2021 were chosen. Chronological and systematic analysis of scientific literature were carried out to perform a PEST analysis in order to form a tool for FinTech sector environment assessment for further testing and validation.

2. Data collection and partial processing. In order to prepare for testing of a newly developed tool, the authors selected eight countries for which the data was collected and partially processed. The authors selected leading FinTech countries according to the Global FinTech Index 2020 (United States, United Kingdom, Singapore, Switzerland, The Netherlands), as well as the Baltic States (Estonia, Latvia, Lithuania) (Findexable, 2019). In order to prepare for testing and validation, data publicly available from the global reports for 2020 was collected and partially processed. In order to standardize the data available, country rankings on a global level expressed as a percentage, were used.

3. Expert evaluations are often used to determine the significance of indicators (Gedvilaite, 2019). Therefore, expert evaluation was used in the paper for this purpose. 8 experts have contributed to the results of this study representing business, science and public sectors with at least 5 years of experience in a position at least as senior manager.

The number of indicators was taken into-account when grouping the indicators in the survey template. Theoretical studies, as well as practical experience, show that experts can assess only a certain number of indicators with sufficient accuracy and reaches maximum of 12 (Ginevičius, 2009). Since the total number of indicators discussed in the paper is more than 12 , they were connected to 4 subsystems - different external environments. As a result, experts were asked to:

- Assess the significance of 8 indicators for the development of FinTech political environment in one hundred parts;

- Assess the significance of 8 indicators for the development of FinTech economic environment in one hundred parts;

- Assess the significance of 8 indicators for the development of FinTech social environment in one hundred parts;

- Assess the significance of 8 indicators for the development of FinTech technological environment in one hundred parts;

- Assess the importance of 4 FinTech sector development subgroups (development of 4 different external environments) for FinTech sector development in one hundred parts.

In order to obtain reliable expert evaluation results, the Kendall's Coefficient of Concordance (W) was calculated, which shows the level of compatibility of the expert opinions, or in other words, the agreement among assessments of experts. The values of the Kendall's Coefficient of Concordance are between 0 and 1 . The value being close to 1 shows that experts' assessments are unanimous and value being close to 0 shows that experts' assessments vary very 
much. The concordance calculation according to Kendall's W coefficient is calculated by each ranked object by the following Formula 1 and Formula 2, which are used when there are no ties in each experts' ranks:

$$
W=\frac{12 S}{n^{2}\left(m^{3}-m\right)},
$$

where: $n$ - the number of experts, $m$ - the number of objects to evaluate.

$$
S=\sum_{i=1}^{m}\left(\sum_{j=1}^{n} r_{i j}-\bar{r}\right)^{2},
$$

where: $S$ - a sum-of-squares statistic over the row sums of ranks $m_{i}, r_{i j}-$ a sum of ranks, $\bar{r}$ - an average of sum of ranks.

4. Determination of the significance of indicators. The average of experts' assessment was calculated and the accumulated data was used for an empirical study.

5. Normalization of indicators' values was performed in order to merge them into a single summative value.

6. Multicriteria assessment. Simple Additive Weighting (SAW) method as a Multicriteria decision support method for expert evaluation was used. The choice of the multi-criteria assessment method ends the compilation of the FinTech environment assessment tool.

The results of the paper were statistically processed using the Microsoft Excel software.

\section{Research results}

After the scientific literature analysis, a composition of an assessment tool for FinTech sector environment, based on PEST analysis of FinTech sector external environmental indicators, was formed, resulting in 4 external environments consisting of 32 indicators, presented in Table 2.

The practical applicability of an assessment tool for FinTech sector environment proposed in the paper was verified on the example of leading FinTech countries, according to the Global FinTech Index 2020 (United States, United Kingdom, Singapore, Switzerland, The Netherlands), as well as the Baltic States (Estonia, Latvia, Lithuania) (Findexable, 2019). Quantitative empirical research was carried out by analyzing the data of external environmental indicators for eight countries publicly available for 2020. The positions of countries in international rankings were converted into a percentage expression, normalized and presented in Table 3 for further calculations.

The significance of the indicators was determined by expert evaluations and is presented in Table 3.8 experts have contributed to the results of this study representing business, science and public sectors with at least 5 years of experience in a position at least as senior manager. In order to obtain reliable expert evaluation results, the Kendall's Coefficient of Concordance (W) was calculated and is presented in Table 4. Evaluating the components of the external environment $\mathrm{W}$ ranges from 0.45 to 0.61 , which indicates some level of agreement between the experts regarding the political, economic, social and technological environments of FinTech sector. However, evaluating the overall external environment $\mathrm{W}$ is equal to 0.17 , which indicates, that the agreement among the experts is weak. The calculated consistency of the experts' opinions does not yet indicate that their assessments can be considered exceptional, therefore, in further future research on the topic of FinTech sector environment assessment, the competence coefficient could be calculated (Baležentis \& Žalimaite, 2011).

Based on the results of the experts' assessment of the significance of the indicators, it can be concluded, that:

- The most significant indicators for assessing the favourableness of the political environment for FinTech sector development in the country, as the main drivers, are openness to business and regulation environment for starting a business, while the least significant indicators are rule of law and political globalization.

- The most significant indicators for assessing the favourableness of the economic environment for FinTech sector development in the country, as the main drivers, are attractiveness and competitiveness of the country as a Fintech nation as well as the leading city as a FinTech city, while the least significant indicators are natural capital and real GDP growth.

- The most significant indicators for assessing the favourableness of the social environment for FinTech sector development in the country, as the main drivers, are talent availability, intellectual capital and innovation, while the least significant indicators are population and social globalization.

- The most significant indicators for assessing the favourableness of the technological environment for FinTech sector development in the country, as the main drivers, are digitalization and telecommunication infrastructure, while the least significant indicators are e-participation and online service.

- The most significant environment for assessing the favourableness of the country's environment for the FinTech sector development is technological, while the least significant environment is social.

In further future research, the least relevant indicators could be removed from the FinTech environment assessment tool or their replacement could be explored. 
Table 3. Normalized values of indicators and their significance determined by experts (source: developed by the authors, 2021)

\begin{tabular}{|c|c|c|c|c|c|c|c|c|c|}
\hline Indicator & Estonia & Latvia & Lithuania & Netherlands & Singapore & Switzerland & UK & US & Significance of the Indicator \\
\hline P1 & 0.124 & 0.153 & 0.124 & 0.062 & 0.134 & 0.107 & 0.134 & 0.162 & 0.110 \\
\hline $\mathrm{P} 2$ & 0.145 & 0.142 & 0.128 & 0.125 & 0.115 & 0.130 & 0.127 & 0.088 & 0.126 \\
\hline $\mathrm{P} 3$ & 0.144 & 0.136 & 0.177 & 0.068 & 0.207 & 0.138 & 0.071 & 0.059 & 0.101 \\
\hline $\mathrm{P} 4$ & 0.119 & 0.084 & 0.104 & 0.163 & 0.165 & 0.172 & 0.117 & 0.077 & 0.194 \\
\hline P5 & 0.126 & 0.113 & 0.116 & 0.131 & 0.133 & 0.135 & 0.124 & 0.123 & 0.138 \\
\hline P6 & 0.109 & 0.106 & 0.110 & 0.151 & 0.079 & 0.149 & 0.152 & 0.144 & 0.063 \\
\hline P7 & 0.139 & 0.130 & 0.123 & 0.131 & 0.147 & 0.086 & 0.136 & 0.107 & 0.180 \\
\hline P8 & 0.127 & 0.098 & 0.115 & 0.130 & 0.137 & 0.132 & 0.135 & 0.126 & 0.089 \\
\hline E1 & 0.125 & 0.036 & 0.139 & 0.134 & 0.141 & 0.136 & 0.143 & 0.145 & 0.171 \\
\hline E2 & 0.098 & 0.007 & 0.127 & 0.135 & 0.171 & 0.111 & 0.175 & 0.176 & 0.151 \\
\hline E3 & 0.131 & 0.122 & 0.120 & 0.137 & 0.138 & 0.133 & 0.123 & 0.095 & 0.143 \\
\hline E4 & 0.142 & 0.126 & 0.102 & 0.103 & 0.156 & 0.159 & 0.117 & 0.095 & 0.110 \\
\hline E5 & 0.112 & 0.107 & 0.114 & 0.132 & 0.140 & 0.138 & 0.121 & 0.136 & 0.136 \\
\hline E6 & 0.229 & 0.222 & 0.192 & 0.033 & 0.001 & 0.127 & 0.023 & 0.173 & 0.085 \\
\hline E7 & 0.130 & 0.106 & 0.206 & 0.126 & 0.103 & 0.127 & 0.043 & 0.159 & 0.091 \\
\hline E8 & 0.092 & 0.180 & 0.182 & 0.083 & 0.021 & 0.184 & 0.191 & 0.069 & 0.113 \\
\hline S1 & 0.085 & 0.068 & 0.070 & 0.149 & 0.144 & 0.159 & 0.161 & 0.163 & 0.136 \\
\hline S2 & 0.122 & 0.108 & 0.105 & 0.127 & 0.138 & 0.133 & 0.136 & 0.132 & 0.156 \\
\hline S3 & 0.050 & 0.058 & 0.070 & 0.155 & 0.101 & 0.119 & 0.212 & 0.234 & 0.081 \\
\hline S4 & 0.118 & 0.112 & 0.114 & 0.133 & 0.131 & 0.137 & 0.129 & 0.126 & 0.116 \\
\hline S5 & 0.147 & 0.121 & 0.115 & 0.145 & 0.142 & 0.151 & 0.118 & 0.061 & 0.104 \\
\hline S6 & 0.118 & 0.107 & 0.121 & 0.123 & 0.134 & 0.137 & 0.134 & 0.125 & 0.079 \\
\hline S7 & 0.126 & 0.106 & 0.078 & 0.140 & 0.132 & 0.124 & 0.142 & 0.150 & 0.195 \\
\hline S8 & 0.080 & 0.071 & 0.075 & 0.169 & 0.137 & 0.166 & 0.155 & 0.148 & 0.133 \\
\hline $\mathrm{T} 1$ & 0.115 & 0.093 & 0.102 & 0.136 & 0.146 & 0.138 & 0.126 & 0.144 & 0.173 \\
\hline $\mathrm{T} 2$ & 0.143 & 0.074 & 0.096 & 0.137 & 0.139 & 0.130 & 0.139 & 0.143 & 0.083 \\
\hline $\mathrm{T} 3$ & 0.113 & 0.107 & 0.122 & 0.132 & 0.139 & 0.140 & 0.113 & 0.132 & 0.136 \\
\hline $\mathrm{T} 4$ & 0.134 & 0.117 & 0.134 & 0.126 & 0.124 & 0.120 & 0.122 & 0.123 & 0.144 \\
\hline T5 & 0.116 & 0.102 & 0.110 & 0.136 & 0.137 & 0.135 & 0.130 & 0.132 & 0.115 \\
\hline T6 & 0.141 & 0.073 & 0.125 & 0.133 & 0.139 & 0.115 & 0.138 & 0.136 & 0.086 \\
\hline $\mathrm{T} 7$ & 0.101 & 0.091 & 0.099 & 0.138 & 0.136 & 0.146 & 0.140 & 0.148 & 0.114 \\
\hline $\mathrm{T} 8$ & 0.129 & 0.117 & 0.114 & 0.131 & 0.123 & 0.132 & 0.127 & 0.127 & 0.150 \\
\hline
\end{tabular}

Table 4. Compatibility of expert assessment (source: developed by the authors, 2021)

\begin{tabular}{|l|c|}
\hline Components of the External Environment & Kendall's Coefficient of Concordance (W) \\
\hline Political Environment & 0.58 \\
\hline Economic Environment & 0.45 \\
\hline Social Environment & 0.61 \\
\hline Technological Environment & 0.55 \\
\hline Overall External Environment & 0.17 \\
\hline
\end{tabular}

In order to assess the performance of each country in each environment, multi-criteria assessment (the SAW method) was used. Every indicator presented in Table 3 was multiplied by its weight, determined by the experts, and the numbers obtained after multiplication were summed in each environment. The results of an empirical study, as the existing values of FinTech sector environment assessment of eight countries, are provided in Table 5.

According to the results of an empirical study of the paper, Switzerland has the most favorable external environment for FinTech sector development. Such result was strongly influenced by the favorable political environment in the country, although Switzerland has achieved relatively good results in assessing all four external environments. The second place is divided between Singapore and United Kingdom, the third - between The Netherlands, United States and Estonia. Lithuania and Latvia have the least favorable environment for FinTech sector development among the countries selected for empirical study. 
Table 5. The results of an empirical study by Multicriteria decision support method SAW (source: developed by the authors, 2021)

\begin{tabular}{|c|c|c|c|c|c|c|c|c|c|}
\hline $\begin{array}{c}\text { Environment / } \\
\text { Country }\end{array}$ & Estonia & Latvia & Lithuania & Netherlands & Singapore & Switzerland & UK & US & $\begin{array}{l}\text { Significance of } \\
\text { the Indicator }\end{array}$ \\
\hline Political & $\bigcirc 0.130$ & $\bigcirc 0.119$ & $\bigcirc 0.123$ & $\bigcirc 0.124$ & $\bigcirc 0.144$ & 0.370 & $\bigcirc 0.124$ & $\bigcirc 0.106$ & 0.245 \\
\hline Economic & 0.127 & $\bigcirc 0.102$ & 0.142 & 0.116 & 0.118 & 0.138 & 0.125 & 0.131 & 0.239 \\
\hline Social & 0.108 & $\bigcirc 0.095$ & $\bigcirc 0.092$ & 0.143 & 0.134 & 0.141 & 0.147 & 0.142 & 0.215 \\
\hline Technological & 0.123 & $\bigcirc 0.100$ & 00.113 & 0.133 & 0.135 & 0.133 & 0.128 & 0.135 & 0.301 \\
\hline Result & $\$ 0.122$ & $\bigcirc 0.104$ & $\bigcirc 0.118$ & 0.129 & 0.133 & 0.194 & $\$ 0.130$ & $\bigcirc 0.129$ & \\
\hline
\end{tabular}

Table 6. The values of FinTech sector environment assessment presented in descending order (source: developed by the authors, 2021)

\begin{tabular}{|l|c|l|l|l|l|l|c|l|l|}
\hline \multicolumn{2}{|c|}{$\begin{array}{c}\text { Political } \\
\text { environment }\end{array}$} & \multicolumn{2}{c|}{$\begin{array}{c}\text { Economic } \\
\text { environment }\end{array}$} & \multicolumn{2}{c|}{$\begin{array}{c}\text { Social } \\
\text { environment }\end{array}$} & \multicolumn{2}{c|}{$\begin{array}{c}\text { Technological } \\
\text { environment }\end{array}$} & \multicolumn{3}{c|}{$\begin{array}{c}\text { Total external } \\
\text { environment }\end{array}$} \\
\hline Switzerland & 0.370 & Lithuania & 0.142 & UK & 0.147 & US & 0.135 & Switzerland & 0.194 \\
\hline Singapore & 0.144 & Switzerland & 0.138 & Netherlands & 0.143 & Singapore & 0.135 & Singapore & 0.133 \\
\hline Estonia & 0.130 & US & 0.131 & US & 0.142 & Netherlands & 0.133 & UK & 0.130 \\
\hline Netherlands & 0.124 & Estonia & 0.127 & Switzerland & 0.141 & Switzerland & 0.133 & Netherlands & 0.129 \\
\hline UK & 0.124 & UK & 0.125 & Singapore & 0.134 & UK & 0.128 & US & 0.129 \\
\hline Lithuania & 0.123 & Singapore & 0.118 & Estonia & 0.108 & Estonia & 0.123 & Estonia & 0.122 \\
\hline Latvia & 0.119 & Netherlands & 0.116 & Latvia & 0.095 & Lithuania & 0.113 & Lithuania & 0.118 \\
\hline US & 0.106 & Latvia & 0.102 & Lithuania & 0.092 & Latvia & 0.100 & Latvia & 0.104 \\
\hline
\end{tabular}

Since one of the objectives of the paper is to provide recommendations for further Lithuanian FinTech sector development, on the basis of empirical research results, the authors make the following recommendations to:

1. Improve the technological environment with a particular focus on digitalization, e-participation, network readiness and research and development $(\mathrm{R} \& \mathrm{D})$, since these indicators are currently behind in their level of development in comparison to the other countries examined in the study. Especially bearing in mind that according to the research findings, that the most significant environment for assessing the favourableness of the country's environment for the FinTech sector development is technological, and according to Table 5 and Table 6, technological environment in Lithuania is not so favourable for FinTech development.

2. Emphasize the favorableness of economic environment as a key argument for FinTech sector development. According to the research findings, provided in Table 5 and Table 6, economic environment in Lithuania is very favorable for FinTech development. The main indicators for such result are attractiveness and competitiveness of the country as a Fintech nation, resource efficiency and intensity, and economic globalization. It can be concluded, that the favorableness of economic environment for FinTech development is one of the main reasons of FinTech sector development success in Lithuania, which also confirms the conclusions of the FinTech Landscape in Lithuania 2020-2021 Report by Invest Lithuania. Therefore, more could be done to the advantage.

3. Pay more attention and efforts to improve the social environment of FinTech sector, since the research has shown, that it is the least significant environment for assessing the favorableness of the country's environment for the FinTech sector development because of indicators like population, quality of life, entrepreneurship and talent availability. However, Lithuania's talent is consistently cited as a key factor for companies when choosing Lithuania to develop and scale their FinTech businesses and according to The FinTech Landscape in Lithuania 2020-2021 Report, 40 percent of global FinTech choose Lithuania because of the talent pool availability, while one of the main challenges experienced by the surveyed FinTechs in 2020 and anticipated in 2021 is attracting qualified and suitable talent (Invest Lithuania, 2021).

4. Improve the political environment with a particular focus on openness to business, political globalization, access to finance and government size, since these are the weak indicators according to the research findings, provided in Table 5 and Table 6, making the favourableness of political environment in Lithuania is lower than medium.

The values of FinTech sector environment assessment in Lithuania shows, that the environment needs improving in order to continue the successful development of the sector. 


\section{Conclusions}

The paper contributes to the scientific literature with the development of a FinTech sector environment assessment tool, resulting in 4 external environments consisting of 32 indicators. The following indicator weights were determined in order of importance: technological environment 0.301 , political environment 0.245 , economic environment 0.215 , social environment 0.215 .

According to the expert evaluation, the main drivers of political environment for FinTech sector development are: openness to business 0.194 , and regulation environment for starting a business 0.194 , the least significant indicators: rule of law 0.089 , and political globalization 0.063 . The main drivers of economic environment are: attractiveness and competitiveness of the country as a Fintech nation 0.171 , as well as the leading city as a FinTech city 0.151 , the least significant indicators: natural capital 0.091, and real GDP growth 0.085 . The main drivers of social environment are: talent availability 0.195 , intellectual capital and innovation 0.156 , the least significant indicators: population 0.081 , and social globalization 0.079 . The main drivers of technological environment are: digitalization 0.173 , and telecommunication infrastructure 0.150 , the least significant indicators: online service 0.086 . and e-participation 0.083 .

According to the results of an empirical study by Multicriteria decision support method SAW, the favorableness of external environment for FinTech sector development in the eight countries studied is assessed as follows in order of importance: Switzerland 0.194, Singapore 0.133, United Kingdom 0.130, The Netherlands 0.129, United States 0.129 , Estonia 0.122 , Lithuania 0.118 , Latvia 0.104 . The most favorable environment in Lithuania is economic 0.142 , the least favorable - social 0.092 .

The paper contributes to the practical level introducing a universal and adaptable FinTech sector environment assessment tool to countries indicating the main drivers of FinTech sector development, giving the opportunity to identify the external environmental factors to improve in order to create better conditions for the development of the FinTech sector.

The paper contributes to the national level and can be used as a part of policy decision making methodologies. The policymakers can use FinTech sector environment assessment tool in order to identify the external environmental factors to improve in order to create better conditions for the development of the national FinTech sector.

Research is based on an assessment of the significance of external environmental indicators of FinTech sector development. Due to the large number of available and possible to include indicators, only a fraction of factors was selected for research. Therefore, the object of the research requires a more detailed study in the future.

The testing of a FinTech sector environment tool is based on the results of eight chosen countries. In order to see a larger picture of the differences of FinTech sector environment between the countries, testing of an assessment tool requires a more detailed study in the future.

In addition, the evaluation of experts requires a calculation of the competence coefficient in the future as well.

\section{Disclosure statement}

The authors do not have any competing financial, professional, or personal interests from other parties.

\section{References}

Arner, D. W., Barberis, J., \& Buckley, R. P. (2015). The evolution of Fintech: A new post-crisis paradigm. Georgetown Journal of International Low, 47, 1271. https://doi.org/10.2139/ssrn.2676553

Baležentis, A., \& Žalimaitè, M. (2011). Ekspertinių vertinimų taikymas inovacijų plètros veiksnių analizèje: Lietuvos inovatyvių i̇monių vertinimas. Vadybos mokslas ir studijos-kaimo verslu ir ju infrastruktūros plètrai, (3), 23-31.

Boitan, I. A., \& Barbu, T. C. (2021). EU FinTech index: An Evaluation of countries' opportunities for FinTech growth. In Fostering innovation and competitiveness with FinTech, RegTech, and SupTech (pp. 1-20). IGI Global. https://doi.org/10.4018/978-1-7998-4390-0.ch001

Chakravorti, B., Chaturvedi, R. S., Filipovic, C., \& Brewer, G. (2020). Digital in the time of Covid. Trust in the digital economy and its evolution across 90 economies as the planet paused for a pandemic. The Fletcher School at Tufts University.

Conceicao, P. (2020). The 2020 human development report. The United Nations Development Programme.

Cornell University, INSEAD, \& WIPO. (2020). The Global innovation index 2020: Who will finance innovation? Ithaca, Fontainebleau, \& Geneva.

Dreher, A. (2006). Does globalization affect growth? Evidence from a new index of globalization. Applied Economics, 38(10), 1091-1110. https://doi.org/10.1080/00036840500392078

EY. (2015). EY FinTech adoption index.

EY. (2017). EY FinTech adoption index: The rapid emergence of FinTech. EY Global Financial Services.

EY. (2019). Global FinTech adoption index 2019: As FinTech becomes the norm, you need to stand out from the crowd. EY Global Financial Services. 
European Commission. (2018). FinTech action plan: For a more competitive and innovative European financial sector. European Commission. (2020). Digital Finance Strategy for the EU. Brussels, 24.9.2020 COM (2020) 591 final.

fDi Intelligence. (2019). FinTech locations of the Future: 2019/20 winners. https://www.fdiintelligence.com/article/75404

Findexable. (2019). The global Fintech index 2020. Findexable Limited (findexable.com) \& The Global Fintech Index.

Frost, J. (2020). The economic forces driving fintech adoption across countries. In King, M. R. \& Nesbitt, R. W. (Eds.), The technological revolution in financial services: How banks, FinTechs, and customers win together (pp. 70-89). University of Toronto Press. https://doi.org/10.3138/9781487533137-006

Nicoletti, B., Nicoletti, W., \& Weis. (2017). Future of FinTech. Palgrave Macmillan. https://doi.org/10.1007/978-3-319-51415-4

Gauthier, J. F., Penzel, M., Kuester, S., Morelix, A., \& Rozynek, M. (2020). The global FinTech ecosystem report 2020 (Startup Genome LLC).

Gedvilaite, D. (2019). The assessment of sustainable development of a countrys' regions [Doctoral Dissertation]. Technika.

Ginevičius, R. (2009). Socioekonominių sistemų būklès kiekybinio įvertinimo problematika. Verslas: teorija ir praktika, 10(2), 69-83. https://doi.org/10.3846/1648-0627.2009.10.69-83

Gygli, S., Haelg, F., Potrafke, N., \& Strum, J. E. (2019). The KOF Globalisation Index - revisited. The Review of International Organizations, 14, 543-574. https://doi.org/10.1007/s11558-019-09344-2

Goo, J. J., \& Heo, J. Y. (2020). The impact of the regulatory sandbox on the fintech industry, with a discussion on the relation between regulatory sandboxes and open innovation. Journal of Open Innovation: Technology, Market, and Complexity, 6(2), 43. https://doi.org/10.3390/joitmc6020043

Gupta, A. (2013). Environment \& PEST analysis: an approach to the external business environment. International Journal of Modern Social Sciences, 2(1), 34-43.

Hieminga, G., Lande, F., \& Nijboer, T. (2016). The FinTech index: Assessing digital and financial inclusion in developing and emerging countries. ING Economics Department, UK, London.

International Monetary Fund. (2020). https://www.imf.org/external/datamapper/datasets/WEO

Invest Lithuania. (2021). The FinTech landscape in Lithuania: 2020-2021 report. https://www.investlithuania.com/wp-content/ uploads/The-Fintech-landscape-in-Lithuania-2020-2021.pdf

KPMG International. (2020). Pulse of FinTech H1 2020. https://assets.kpmg/content/dam/kpmg/xx/pdf/2020/09/pulse-of-fintech-h1-2020.pdf

KOF Swiss Economic Institute. (2020). KOF Globalisation Index 2020. https://kof.ethz.ch/en/forecasts-and-indicators/indicators/ kof-globalisation-index.html

ManpowerGroup Talent Solutions. (2020). Total workforce index 2020 global analysis. ManpowerGroup Talent Solutions.

Mention, A. L. (2019). The future of Fintech. Research-Technology Management, 62(4), 59-63. https://doi.org/10.1080/08956308.2019.1613123

Miller, T., Kim, A. B., \& Roberts, J. M. (2020). Index of economic freedom. The Heritage Foundation.

Morris, H., Wardle, M., \& Mainelli, M. (2021). The global financial centres index 29.

National Cyber Security Index. (2021). https://ncsi.ega.ee/ncsi-index/

Portulans Institute. (2020). The network readiness index 2020: Accelerating digital transformation in a post-COVID global economy.

Sahay, M. R., von Allmen, M. U. E., Lahreche, M. A., Khera, P., Ogawa, M. S., Bazarbash, M., \& Beaton, M. K. (2020). The promise of fintech: Financial inclusion in the post COVID-19 era. International Monetary Fund.

Shtal, T., Buriak, M., Ukubassova, G., Amirbekuly, Y., Toiboldinova, Z., \& Tlegen, T. (2018). Methods of analysis of the external environment of business activities. https://www.revistaespacios.com/a18v39n12/a18v39n12p22.pdf

Speedtest. (2020). Speedtest global index $2020 \mathrm{https} / / /$ www.speedtest.net/global-index

SolAbility. (2020). The sustainable competitiveness report (9th ed.). SolAbility Sustainable Intelligence.

Tirmaste, K., Voolma, L., Laidroo, L., Kukk, M. L., \& Avarmaa, M. (2019). FinTech report Estonia 2019. TalTech School of Business and Governance, Department of Economics and Finance, in co-operation with financeestonia.eu.

U.S.News., \& World Report LP. (2020). Best countries 2020: Global rankings, international news and data insights.

United Nations. (2020). E-participation index 2020. UN E-Government Knowledgebase. https://publicadministration.un.org/ egovkb/en-us/Data/Compare-Countries

Vlados, C., \& Chatzinikolaou, D. (2019). Methodological redirections for an evolutionary approach of the external business environment. Journal of Management and Sustainability, 9(2), 25. https://doi.org/10.5539/jms.v9n2p25

World Bank. (2019). Doing business 2020. 